УДК 662.987.697.7

\title{
I.O. Котов
}

Одеський національний політехнічний університет, пр. Шевченка, 1, Одеса, 65044

\section{ПЕРСПЕКТИВИ ВПРОВАДЖЕННЯ ІНТЕГРОВАНИХ ТЕПЛОНАСОСНИХ СИСТЕМ ЕНЕРГОПОСТАЧАННЯ 3 ДВИГУНОМ СТИРЛІНГА ДЛЯ ФЕРМЕРСКИХ ГОСПО- ДАРСТВ}

\begin{abstract}
Розглянуто перспективи впровадження автономних інтегрованих теплонасосних систем енергопостачання з використанням двигуна Стирлінга, щуо працює на біопаливі для фермерських господарств. Показано, щзо иляхом використання двигуна Стирлінга, щуо працює на біопаливі вирішується важливе народногосподарське питання утилізації біомаси, щз приводить до поліпшення екологічного стану довкілля та сталого енергозабезпечення фермерських господарств.
\end{abstract}

Ключові слова: Двигун Стирлінга - Інтегрована система енергопостачання - Біопаливо Ефективність - Тепловий насос

\section{П.А. Котов}

Одесский национальный политехнический университет, пр. Шевченко, 1, Одесса, 65044

\section{ПЕРСПЕКТИВЫ ВНЕДРЕНИЯ ИНТЕГРИРОВАННЫХ ТЕПЛОНАСОСНЫХ СИСТЕМ ЭНЕРГОСНАБЖЕНИЯ С ДВИГАТЕЛЕМ СТИРЛИНГА ДЛЯ ФЕРМЕРСКИХ ХОЗЯЙСТВ}

\begin{abstract}
Рассмотрены перспективы внедрения автономных интегрированных теплонасосных систем энергоснабжения с использованием двигателя Стирлинга, работающего на биотопливе для фермерских хозяйств. Показано, что путем использования двигателя Стирлинга, работающего, на биотопливе решается важный народнохозяйственный вопрос утилизации биомассы, что приводит к улучшению экологического состояния окружающей среды и устойчивого энергообеспечения фермерских хозяйств.
\end{abstract}

Ключевые слова: Двигатель Стирлинга - Интегрированная система энергоснабжения Биотопливо - Эффективность - Тепловой насос

\section{I. ВСТУП}

Наслідки спалювання традиційних видів палива, добре відомі. Велика кількість парникових газів вносить суттєвий внесок в глобальне потепління, а постійно зростаючі ціни на газ і нафту стимулюють дослідження ефективності використання відновлюваних джерел енергії (ВДЕ) (біопалива) для теплових двигунів.

Велика кількість агропромислових комплексів (АПК) і фермерських господарств (ФГ) України знаходяться поза межами централізованого енергопостачання. Дизельні електростанції, за допомогою яких здійснюється енергопостачання великих АПК та ФГ, витрачають надмірну кількість дизельного пального, вартість якого неухильно зростає, а перебої у доставці пального трапляються достатньо часто.

У зонах централізованого енергопостачання через надзвичайно поганий стан сільських електромереж виникають часті відключення ФГ, а в деяких зонах, через брак електричної потужності відключення проводиться кілька разів на добу. Все це призводить до зменшення продуктивності тваринництва, птахівництва, виробництва молока та інших продуктів харчування. Ряд АПК географічно розташовані у зоні розташування міст та місць масового відпочинку населення тому додатково виникає екологічна проблема щодо шкідливих викидів в атмосферу. У цих місцях здійснення енергопостачання за допомогою інтегрованих теплонасосних систем енергопостачання (ITCE) 3 двигуном Стирлінга (ДС), що працює на біопаливі - $\epsilon$ доцільним. Комплексний підхід до вирішення цієї проблеми дозволить ліквідувати численні неекономічні дрібні котельні та зменшить забруднення довкілля.

\section{II. ОСОБЛИВОСТІ ІТСЕ 3 ДС, ЩО ПРАЦЮЄ НА БІОПАЛИВІ}

Впровадження ITCE $з$ ДС, що працює на біопаливі, дозволить вирішити ряд важливих проблем сучасної забезпеченості енергопостачання АПК та ФГ країни:

- створення автономних джерел енергопостачання об'єктів АПК та ФГ;

- децентралізація енергопостачання, підвищення їх надійності та ресурсозбереження;

- широке використання місцевих джерел енергіï;

- забезпечення екологічної чистоти виробництва та споживання енергії для потреб індивідуального сектора. 
На Україні тільки на великих свинарських і птахівницьких підприємствах щорічно утвориться більше 3 млн. тон органічних відходів по сухій речовині, переробка яких дозволить одержати близько 1 млн. т.у.п. у вигляді біогазу, що еквівалентно 8 млрд. кВт/год. електроенергії. Крім того, в Україні є багато не газифікованих ФГ [1]. Для цих господарств дуже важливі розробки автономних систем енергопостачання $з$ використанням біомаси.

Аналіз щодо економічно доцільного річного потенціалу біомаси на Україні становить близько 30 мільйонів т.у.п., що може задовольнити до $18 \%$ [2] потреб України в первинній енергії. Основними складовими потенціалу $є$ відходи сільського господарства та енергетичні культури.

Блок-схема ITCE 3 ДС, яка наведена на рисунку 1 складається 3 наступних елементів, кожен 3 яких впливає на ефективність їі роботи:

- ВДЕ (біопаливо);

-ITCE з використанням ДС, що працює на біопаливі;

- об'єкт теплопостачання - АПК, ФГ або індивідуальний споживач.

Горючий газ, що виробляється з біопалива по своєї теплотворної здатності $\left(20100 \ldots 25100\right.$ кДж/м $\left.{ }^{3}\right)$ [3], зіставлений 3 керосином, вугіллям і бутаном у 1,5-3 рази дешевший їх за вартістю при одночасному додержані екологічних вимог. За допомогою ITCE з ДС не тільки ви- робляється необхідне паливо, а ще й утилізуються різноманітні господарські відходи, в наслідок чого робляться непотрібними очисні споруди, а також інші заходи, що пов'язані із захистом навколишнього середовища.

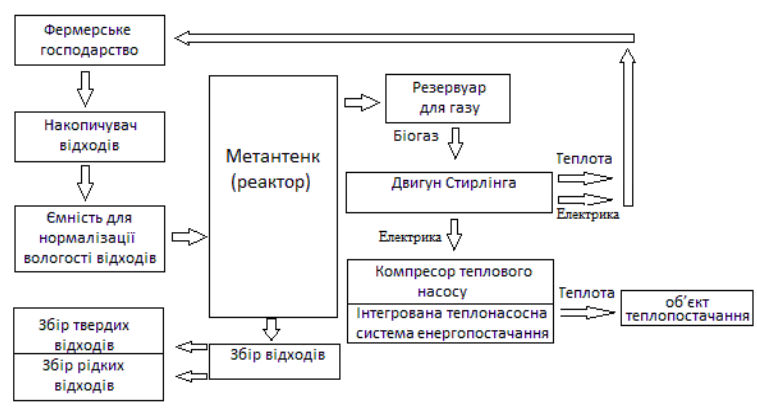

Рисунок 1 - Блок-схема ITCE з ДС, щ̧о праџฺює на біопаливі.

ДС внаслідок особливостей робочого процесу, мають в порівнянні з відомими у даний час іншими тепловими двигунами, низьку токсичність продуктів згоряння за всіма компонентами і особливо по окислам азоту та вуглецю при їх роботі на будь-якому відомому у даний час вуглеводневому паливі. Зіставлення токсичних складових відпрацьованих газів у теплових двигунах різного типу наведено у таблиці 1.

Таблиця 1 - Зміст токсичних компонентів у випускних газах двигунів

\begin{tabular}{|c|c|c|c|}
\hline Двигуни & \multicolumn{3}{|c|}{ Зміст компонентів, мільйонні частки обсягу } \\
\hline & $\mathrm{NO}$ & $\mathrm{CO}$ & $\mathrm{CxHY}$ \\
\hline Двигун Стирлінга & $100 \ldots 200$ & $50 \ldots 200$ & $0,5 \ldots 3$ \\
\hline $\begin{array}{c}\text { Газова турбіна } \\
\text { (з регенеративним теп- } \\
\text { лообмінником) }\end{array}$ & $90 \ldots 250$ & $250 \ldots 450$ & $0,5 \ldots 3$ \\
\hline Дизель & $400 \ldots 2000$ & $200 \ldots 5000$ & $200 \ldots 4000$ \\
\hline Бензиновий двигун & $600 \ldots 2000$ & $40000 \ldots 100000$ & $5000 \ldots 40000$ \\
\hline
\end{tabular}

У вказаній системі перетворюється практично всі відходи біологічного походження, виробляючи паливо, яке використовує у так званому «промисловому» теплонасосному циклі 3 ДС, 3 метою забезпечення виробничих приміщень тепловою та електричною енергією, а частка електричної енергії (20 \%) використовується для приводу компресора теплового насосу (ТН).

\section{III. ТЕХНОЛОГІЧНІ ОСОБЛИВОСТІ ІТСЕ 3 ДС, ЩО ПРАЦЮЕ НА БІОПАЛИВІ}

Особливістю цієї системи є відсутність потреби у протягуванні газопроводу, лінії електропередачі та встановлення резервного дизель генератору. Витрати на експлуатацію установки мізерні і становлять 1,5-2\% від їі вартості на рік [4]. Всією системою управляє система автоматики, яка контролює роботу насосної станції, мішалок, системи підігріву, газової автоматики, ДС. Для управління достатньо всього 1 людини, ця людина веде контроль за допомогою звичайного комп'ютера. Теплова схема ITCE з ДС, що працює на біопаливі потужністю до 100 кВт наведена на рисунку 2.

Перед тим, як біопаливо потрапляє до бункеру завантаження 2 рідка біомаса перекачується насосами, тверда біомаса доставляються по транспортерній стрічці. Рідкі відходи потрапляють не прямо в реактор, а в попередню ємність. Тверда біомаса може загружатися в ємність 3 рідкою біомасою та перемішуватися 3 нею. Після бункеру завантаження біомаса потрапляє до реактору 1 . Підігрів реактора ведеться теплою водою, що надходить 3 ITCE. Середній час гідравлічного відстоювання всередині реактора (залежно від субстратів) становить 20-40 діб, контроль стану ведеться через люк для доступу в реактор 3. Біогаз зберігається в ємності для зберігання газу - газгольдері 4, 3 газгольдера через систему відведення біогазу 6 йде безперервна подача біогазу в камеру згоряння 
8, а отримана теплова енергія на ДС 7, далі частка електричної енергії від ДС використовується для привода компресора ТН 9 та для задоволення потреб промислового виробництва.

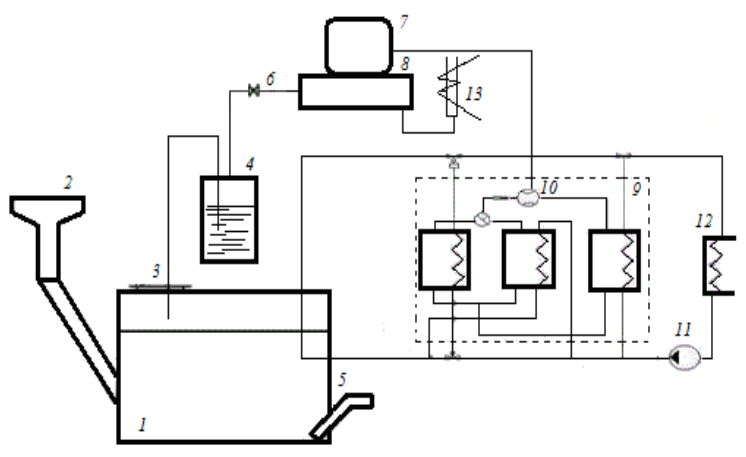

Рисунок 2 - Теплова схема ITCE з ДС, що працює на біопаливі

1 -реактор; 2 - бункер завантаження; 3 -люк для доступу в реактор; 4 - газгольдер; 5 - вивантажувальна труба; 6 - відведення біогазу; 7 - ДС; 8 - камера згоряння; 11 - насос; 9 - теплонасосна установка; 10 - компресор теплового насосу; 12 система опалення; 13 - теплообмінник.

Для аналізу та оцінки ефективності ITCE 3 ДС була розроблена схема енергетичного балансу, яка дозволяє визначати втрати теплової енергії. На рисунку 3 покано входи і виходи енергетичної продукції цієї системи. Паливо і повітря потрапляють в камеру згоряння і виділяють тепло, яке використовується в ДС для виробництва електроенергії та тепла, яке зняте за допомогою охолоджуючої рідини.

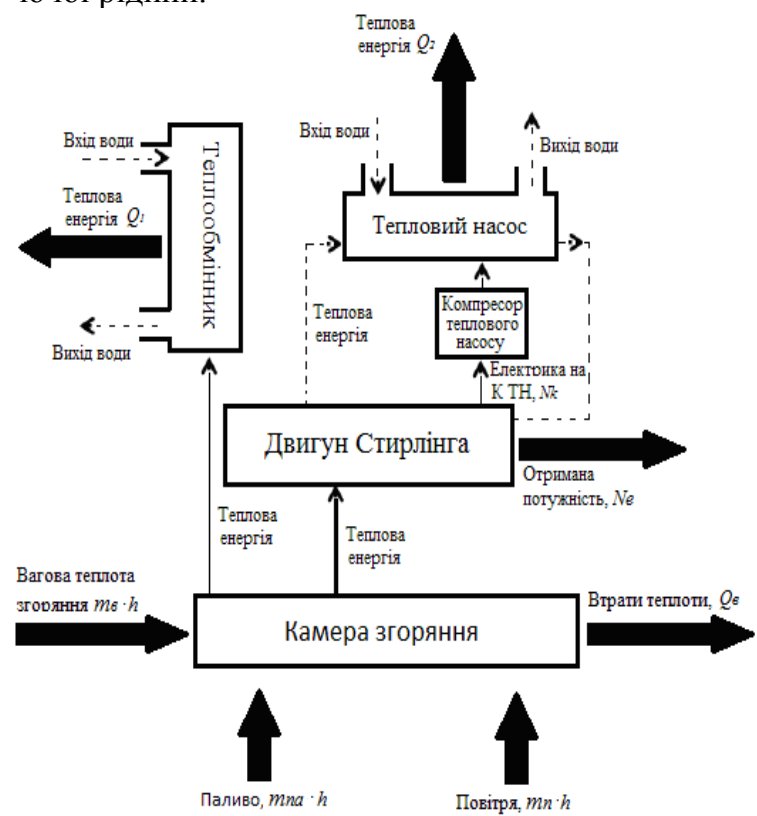

Рисунок 3 - Схема енергетичного балансу ITCE з ДС

Частина енергії від ДС використовується для компресора ТН, а решту енергія потім пропуска- ють через ТН, який захоплює більше тепла. Енергія, що не перетворюється в електричну або не використана в ТН вважається втратами з системи у вигляді тепла, що відходить, або через вихлопні труби або камеру згоряння [5].

\section{IV. МЕТОДИКА ВИЗНАЧЕННЯ ЕФЕКТИВ- НОСТІ ВИКОРИСТАННЯ ІТСЕ 3 ДС}

Енергетичний баланс може бути застосований до визначення входів і виходів енергетичної продукції, як показано в рівнянні 1. Умови зліва представляють енергетичні входи, праворуч - енергетична продукція. Втрати тепла $\sum Q_{b}$ розраховується $з$ використанням рівняння енергетичного балансу за умовою, що робоча рідина на виході 3 ТН охолоджується до температури навколишнього середовища.

$$
m_{n} a \cdot h+m n \cdot h+m \cdot h=N e+N_{k}+Q_{1}+Q_{2}+\sum Q_{\text {s }}
$$

де $m_{n a}, m_{n}, m_{6}$ - масова витрата палива, повітря та води, кг/с; $h$ - ентальпія, кДж/кг; Ne, $N k$ - потужність, кВт; $Q 1, Q 2$ - теплова енергія, кДж; $\sum Q_{b}-$ втрати теплоти, кВт.

Використовуючи енергетичний баланс, ефективність використання енергії системи може бути обчислена, згідно рівнянь 2.

$$
\begin{gathered}
\eta=\frac{N e+N_{k}+Q_{1}+Q_{2}}{m n a \cdot h+m n \cdot h+m_{\boldsymbol{B}} \cdot h} \\
\eta=\frac{N e+N_{k}}{m n a \cdot h+m n \cdot h+m_{B \boldsymbol{B}} \cdot h}+\frac{Q_{1}+Q_{2}}{m n a \cdot h+m n \cdot h+m_{\boldsymbol{B}} \cdot h} \\
\eta=\eta_{\text {електрична }}+\eta_{\text {теплова }}
\end{gathered}
$$

Теплова потужність теплообмінників

$$
Q=m_{B} \cdot C_{p} \cdot \Delta T
$$

де $C_{p}$ - питома теплоємність води, Дж/(кг К); $\Delta T-$ перепаду температур води на вході і виході з теплообмінника, ${ }^{\circ} \mathrm{C}$.

Під час роботи, значна втрата тепла може спостерігатися 3 камери згоряння. Це призводить до значного зниження ефективності системи, тому необхідно ці втрати максимально мінімізувати. На підставі енергетичного балансу більшість теплових втрат показано на рисунку 4, які теоретично можуть бути під час роботи в інтервалі від 0 3600 секунд. Якщо втрати тепла через камеру згоряння будуть ліквідований в той час як решта ITСЕ $з$ ДС залишиться як $\epsilon$, то це буде очікувана енергетична ефективність системи. На рисунку 5 , показано, як підвищується ефективність системи за рахунок зменшення теплових втрат.

\section{V. ВИСНОВКИ}

Впровадження ITCE з ДС, що працює на біопаливі дозволить збільшити значення коефіцієнту заміщення традиційного палива за рахунок використання відновлювальних джерел енергії (біопа- 
ливо) та покращити стан довкілля за рахунок зменшення емісії продуктів згоряння до навколишнього середовища.

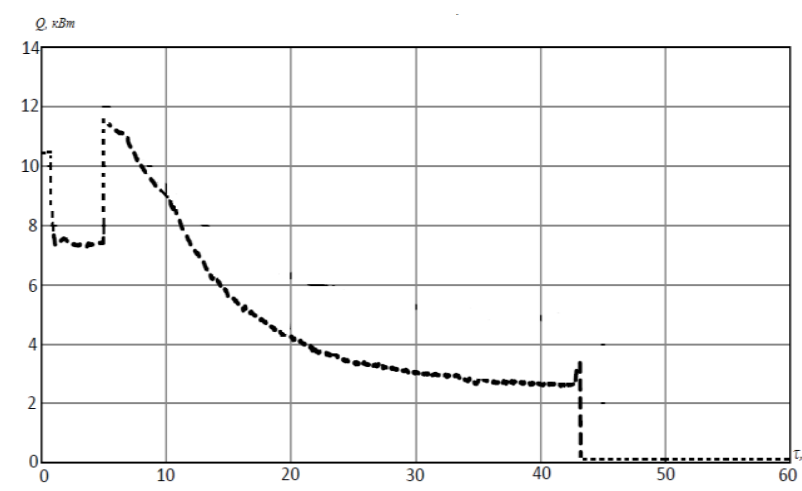

Рисунок 4 - Теплові втрати ITCЕ з ДС

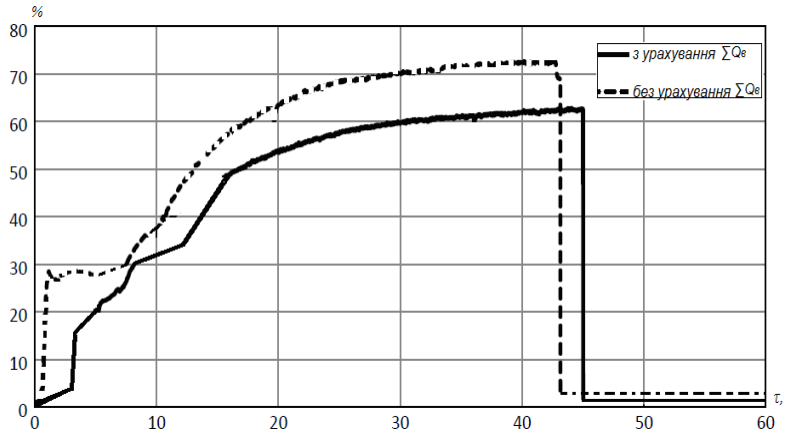

Рисунок 5 - Порівняння ефективності ITCE з ДС

\section{P.A. Kotov}

Odessa National Polytechnic University, 1 Shevchenko str., Odessa, 65044

\section{PROSPECTS FOR IMPLEMENTATION OF INTEGRATED HEAT PUMP ENERGY SYSTEMS WITH STIRLING ENGINE FOR FARMS}

A large number of agro-industrial complexes and farms in Ukraine are outside the centralized power supply and rising prices for gas and oil stimulate research of the effectiveness of integrated autonomous power supply systems based on renewable energy sources. So, implementation of power supply with integrated heat pump energy systems with Stirling engine running on biofuel is appropriate. Integrated power systems with Stirling engine utilization not only gives necessary fuel, but also different household wastes are recycled, that make treatment facilities unnecessary, as well as other measures related to the protection of the environment. Implementation of the above-mentioned system will solve a number of essential problems of of security of energy supply for modern agro-industrial complexes and farms of the country.

Keywords: Stirling engine - Integrated power system - Biofuels - Efficiency - Heat pump

\section{REFERENCES}

1. Rei, D. Teplovie nasosy [Heat pumps]/ D. Rei, D. Makmail. - M.: Energoizdat [Energy publishing], 1982. $-224 \mathrm{p}$.

2. Denisova, A. E. Ocenka effiktivnosti raboty kompleksnoi alternativnoi sistemy teplosnabgeniya [Evaluating the effectiveness of a comprehensive alternative heating system] / A.E. Denisova A. S. Mazurenko // Tr. Odes. politehn. Un-ta, Odessa [Proceedings of the Polytechnic University], 2000. - Vyp. 2(11). - PP. $95-$ 97.

3. Korshemyi, M. Energozberegennya v agropromislovomu kompleksi [Power save in the agroindustrial complex] / V. Scerban, M. Korshemyi, V.
Fedorenko. - Ternopil: Pidrushn. i pisibn. [Textbooks and manuals], 2001. - $984 \mathrm{p}$.

4. Kotov P.O. Perspektivy vykorystannay dvyguniv zovnishniogo zgorannya dla integrovanoi teplonasosnoi systemu teplopostashannay [Prospects for the use of external combustion engenes for integrated heat pump heating system] / P.O. Kotov, A.E. Denisova // Holodil. tehnika i tehnologiya. Odessa [Refrigeration eng. and technology], 2010. - № 5 (127). - pp. 30 - 33.

5. Lin M. Combination of a Biomass Fired Updraft Gasified and a Stirling Engine for Power Production / M. Lin // Journal of Energy Resources Technology, 2007. vol. 129 , pp. $66-70$.

Отримана в редакції 28.03.2014, прийнята до друку 29.04.2014 
